\title{
Assessment of Knowledge and Attitude Among College Students Toward Umbilical Cord Blood and its Banking
}

\author{
Namita Yadav, ${ }^{1,2}$ Vita Leena D'Souza, ${ }^{2}$ Geethamani $T^{2}$ \\ ${ }^{1}$ Nursing Programme, Manipal College of Medical Sciences, Pokhara, Kaski, Nepal; \\ ${ }^{2}$ East West College of Nursing, Bangalore, India. \\ Namita Yadav. Email: atimanray@gmail.com
}

Introduction: Umbilical cord blood (UCB) is a good source of haematopoietic stem cells and progenitor cells. UCB stem cells are used in treatment of a variety of blood and bone marrow diseases, blood cancers, metabolic disorders and immune deficiencies.

Objective: This study aimed in investigating college students' knowledge and attitude about UCB and UCB banking.

Methods: It is a descriptive cross-sectional study. The study was conducted in East West College of Management, Bangalore, India from September 2018 to August 2019. A total 80 college students were selected by random sampling techniques. There were self-structured questionnaires used to assess the knowledge and attitude regarding UCB and UCB banking. The data analysis was done using descriptive and inferential statistics in SPSS version 21.

Results: The maximum number of participants were from age group 19-21 years followed by age group 16-18 years. The overall knowledge score was $21.05 \pm 5.11$ with mean percentage score of 60.14 . The $71.25 \%$ (57) of subjects had moderately adequate knowledge; whereas, 25\% (20) of subjects showed adequate knowledge. Similarly, the overall attitude score of subjects was $61.5 \pm 5.17$ with a mean percentage score of 51.25\%. Out of the total participants, 90\% (72) had neutral attitude, 10\% (8) exhibited positive attitude and none of the subjects exhibited negative attitude towards UCB banking. There was no association found between knowledge and sociodemographic variables and between attitude and sociodemographic variables.

Conclusion: The majority of the respondents had moderate knowledge and maximum had neutral attitude on umbilical cord blood and umbilical cord blood banking.

Key words: Attitude; Knowledge; Fetal blood; Students.

Submitted: May 23, 2021 Accepted: June 20, 2021 Published: June 28, 2021

\section{INTRODUCTION}

Umbilical cord blood (UCB) is a good source of haematopoietic and progenitor cells. Cord blood is a very significant alternative source of stem cells for all allogenic transplantations. ${ }^{1,2}$ UCB stem cells are used in treatment of a variety of blood and bone marrow diseases, blood cancers, metabolic disorders and immune deficiencies. ${ }^{2-4}$ It has many positive points, like it is easily available, storable, readily usable, tissue rejection is seen less frequent after cord blood transplantation due to the low immune capacity of fetal blood cells. ${ }^{2,5,6}$ In 1993, the first public UCB bank was set up in New York, USA ${ }^{7}$ and currently there are about 225,000 cord blood units frozen in 38 public cord

Citation: Yadav N, D’Souza VL, Geethamani T. Assessment of knowledge and attitude among college students toward umbilical cord blood and its banking. Nepal J Health Sci. 2021 Jan-Jun;1(1): 1-7 
blood banks in 25 countries. $^{8}$ The entire process of collection, processing, testing and cryopreservation of cord blood is quite cumbersome and unregulated and this leads to a loss of 10 to 20 percent of the initially collected blood volume and cell counts. ${ }^{4,9}$ Cord blood banking requires storing of UCB in liquid nitrogen for long periods of time. In modern laboratories, cord blood can be preserved for up to 15 years. ${ }^{10}$ This study is aimed at investigating college students' knowledge and attitudes about UCB and UCB banking.

\section{MethodS}

It is a descriptive cross-sectional study. The study was conducted in East West College of Management, Bangalore, India from September 2018 to August 2019. A total of 80 college students were selected by random sampling techniques. The inclusion criteria were college students of both sexes, and non-medical students. The exclusion criteria were students who are not willing to participate and students who are absent at the time of data collection. Self-structured questionnaire was used to assess the knowledge and attitude regarding UCB and UCB banking. The data were collected after taking consent of participants. The ethical approval was taken from ethical committee of East West College of Nursing, Bangalore; India.The data analysis was done using descriptive and inferential statistics in SPSS version 21. $\mathrm{P}$ value $<0.05$ was considered as statistically significant.

The questionnaires used had following sections:

Section A: Demographic characteristics such as age, sex, religion, type of family, family income, previous knowledge, source of information regarding UCB and UCB banking.

Section B: Structured knowledge questionnaire consisted of 35 items. Different aspects covered were as follows: general information (12, 34.29\%), procedure of umbilical cord blood banking $(12,34.29 \%)$ and services for umbilical cord blood banking (11, 31.42\%). One mark was allotted for correct answer and zero for incorrect answer. A total of 35 score was given for knowledge part of questionnaire. Level of knowledge was interpreted as: Inadequate knowledge $<50 \%$, moderately adequate knowledge $50-75 \%$ and adequate knowledge $>75 \%$

Section C: Structured opinionnaire was prepared in a 5 -point scale with the scores ranging from 1 to 5 (strongly disagree: 1, disagree: 2, undecided: 3, agree:
4, and strongly agree: 5 ) with the total number of attitude question of 24 and maximum attitude point score of 5. The maximum score for opinionnaire was 120. The quality of attitude was determined as follows: unfavorable attitude $<50 \%$, neutral attitude 50-75\% and favorable attitude $>75 \%$.

Questionnaire validity and reliability

Questionnaire was validated by nine nursing experts in the field of Obstetrics and Gynaecological Nursing and expert Biostatistician. The reliability was established by using split- half method for the knowledge questionnaire. The reliability score obtained was r' = 0.9. Reliability for attitude scale was obtained by using Cronbach's Alpha. The obtained value of $\alpha$ was 0.604 which shows high reliability of the tool.

\section{RESUlTS}

A total of 80 participants were included, out of which $39(48.75 \%)$ were male and $41(51.25 \%)$ were female. Most of them $(53,66.25 \%)$ were from 19-21 years age group followed by $(26,32.5 \%)$ 16-18 years age group and the least $(1,1.25 \%)$ was from $22-24$ years age group. The maximum participants were Hindu (75, 93.75\%), followed by others (3, 3.75\%), Christian (1, $1.25 \%)$ and Muslim (1, 1.25\%). The majority participants were from nuclear family $(60,75 \%)$, followed by Joint family $(16,20 \%)$, single parent family (3, $3.75 \%)$ and extended family $(1,1.25 \%)$. The maximum number of participants belonged to good income family $(28,35 \%)$ that is 5 -10 lakh income per year followed by 10-15 lakh income $(18,22.5 \%)$ and less than 5 lakh per year $(18,22.5 \%)$ and more than 15 lakh (16, $20 \%) .60 \%$ of participants had previous knowledge about umbilical cord blood and cord blood banking. Most of them had received previous knowledge from electronic resources $(16,33.33 \%)$, health professionals (12, 25\%), print media (10, 20.83\%), friends and relatives $(8,16.67 \%)$ and news or pamphlets of cord blood bank (2, 4.17\%).

The highest mean \pm SD observed was $8.5 \pm 1.56$ and mean percentage for knowledge on general information regarding UCB and UCB bank was 70.8\%. Similarly, lowest mean \pm SD observed was $5.80 \pm 1.60$ and mean percentage for knowledge of services available for UCB and UCB bank was 52.72\%. The overall knowledge mean \pm SD was $21.05 \pm 5.11$ with mean 
percentage of $60.14 \%$ (Table 1 ).

Fifty Seven (71.25\%) subjects had moderately adequate knowledge; whereas 20 (25\%) subjects showed adequate knowledge and $3(3.75 \%)$ subjects had inadequate knowledge regarding area of general information of UCB and UCB bank. Similarly, 56 (70\%) had moderately adequate knowledge in area of procedure of UCB and UCB bank and in the same way 45 (56.25\%) had moderately adequate knowledge in area of services available for UCB and UCB bank. The overall knowledge assessment showed that 70 (87.5\%) subjects had moderately adequate knowledge' 6 (7.5\%) of subjects had inadequate knowledge and 4 (5\%) of subjects exhibited adequate knowledge regarding UCB and UCB bank (Table 2).

The overall mean \pm SD attitude score of subjects was $61.5 \pm 5.17$ with a mean percentage score of $51.25 \%$ [Table 3] and maximum number of subjects $(72,90 \%)$ had neutral attitude, followed by favorable attitude
$(8,10 \%)$ and none of the subjects exhibited unfavorable attitude towards UCB and UCB bank (Table 4).

The calculated chi-square $\left(\chi^{2}\right)$ values were less than table values at $\mathrm{P} \leq 0.05$ (level of significance) in terms of college student, age, sex, religion, types of family, family income per year, previous knowledge and source of knowledge. No significant association between knowledge and selected socio-demographic variables was found (Table 5). Similarly, there was no significant association found between attitude and sociodemographic variables (Table 6).

Table 1: Knowledge scores of college students regarding umbilical cord blood (UCB)and umbilical cord blood banking (UCBB).

\begin{tabular}{|l|c|c|c|}
\hline \multicolumn{1}{|c|}{ Areas of knowledge } & Maximum score & Mean \pm SD & $\begin{array}{c}\text { Mean percentage } \\
\text { (\%) }\end{array}$ \\
\hline $\begin{array}{l}\text { General information regard- } \\
\text { ing UCB and UCBB }\end{array}$ & 12 & $8.5 \pm 1.56$ & 70.8 \\
\hline $\begin{array}{l}\text { Procedure of UCB and UCBB } \\
\text { Services available for UCB } \\
\text { and UCBB }\end{array}$ & 12 & $6.75 \pm 1.95$ & 56.25 \\
\hline Over all knowledge score & $\mathbf{3 5}$ & $5.80 \pm 1.60$ & 52.72 \\
\hline
\end{tabular}

Table 2: Distribution of knowledge of college students regarding umbilical cord blood(UCB) and umbilical cord blood banking(UCBB).

\begin{tabular}{|l|c|c|c|}
\hline \multirow{2}{*}{ Areas of knowledge } & $\begin{array}{c}\text { Inadequate } \\
\text { knowledge }\end{array}$ & $\begin{array}{c}\text { Moderately adequate } \\
\text { knowledge }\end{array}$ & $\begin{array}{c}\text { Adequate } \\
\text { knowledge }\end{array}$ \\
\cline { 2 - 4 } & $\mathrm{n}(\%)$ & $\mathrm{n}(\%)$ & $\mathrm{n}(\%)$ \\
\hline $\begin{array}{l}\text { General information re- } \\
\text { garding UCB and UCBB }\end{array}$ & $3(3.75)$ & $57(71.25)$ & $20(25)$ \\
\hline $\begin{array}{l}\text { Procedure of UCB and } \\
\text { UCBB }\end{array}$ & $21(26.25)$ & $56(70)$ & $3(3.75)$ \\
\hline $\begin{array}{l}\text { Services available for } \\
\text { UCB and UCBB }\end{array}$ & $32(40)$ & $45(56.25)$ & $3(3.75)$ \\
\hline $\begin{array}{l}\text { Over all knowledge } \\
\text { score }\end{array}$ & $\mathbf{6 ( 7 . 5 )}$ & $\mathbf{7 0 ~ ( 8 7 . 5 )}$ & $\mathbf{4 ( 5 )}$ \\
\hline
\end{tabular}


Table 3: Attitude of college students regarding umbilical cord blood(UCB) and umbilical cord blood banking(UCBB).

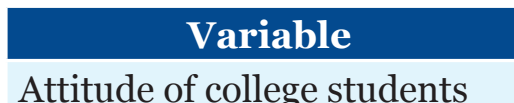

towards UCB and UCBB

\section{Maximum score}

120

\section{$\operatorname{Mean} \pm$ SD}

$61.5 \pm 5.17$
Mean percentage (\%)

51.25

Table 4: Distribution of Attitude of college students regarding umbilical cord blood (UCB) and umbilical cord blood banking (UCBB).

\begin{tabular}{|l|c|c|c|}
\hline \multicolumn{1}{|c|}{ Attitude variable } & $\begin{array}{c}\text { Unfavourable } \\
\text { attitude }<\mathbf{5 0} \%\end{array}$ & $\begin{array}{c}\text { Neutralattitude } \\
\mathbf{5 0 - 7 5 \%}\end{array}$ & $\begin{array}{c}\text { Favourable } \\
\text { attitude }>\mathbf{7 5} \%\end{array}$ \\
\cline { 2 - 4 } & $\mathrm{n}(\%)$ & $\mathrm{n}(\%)$ & $\mathrm{n}(\%)$ \\
\hline $\begin{array}{l}\text { Attitude of college stu- } \\
\text { dents regarding UCB and }\end{array}$ & - & $72(90)$ & $8(10)$ \\
\hline UCBB & & & \\
\hline
\end{tabular}

Table:5 Association of level of knowledge with age, sex and religion

\begin{tabular}{|c|c|c|c|c|c|}
\hline \multirow{2}{*}{$\begin{array}{l}\text { S.I } \\
\text { no }\end{array}$} & \multirow{2}{*}{$\begin{array}{c}\text { Socio-demographic } \\
\text { variables }\end{array}$} & Inadequate & $\begin{array}{c}\text { Moderately } \\
\text { adequate }\end{array}$ & Adequate & \multirow[t]{2}{*}{$x^{2}$ value } \\
\hline & & $\mathrm{n}$ & $\mathrm{n}$ & $\mathrm{N}$ & \\
\hline \multirow[t]{5}{*}{1} & \multicolumn{4}{|l|}{ Age in years } & \multirow{5}{*}{$\begin{array}{c}\chi^{2}=12.59 \\
\mathrm{df}=6 \\
\mathrm{NS}\end{array}$} \\
\hline & $16-18$ years & 2 & 22 & 2 & \\
\hline & 19-21 years & 4 & 47 & 2 & \\
\hline & 22-24 years & - & 1 & - & \\
\hline & $25-27$ years & - & - & - & \\
\hline \multirow[t]{3}{*}{2} & Sex & & & & \multirow{3}{*}{$\begin{array}{c}\chi_{2}=5.99 \\
\mathrm{df}=2 \\
\mathrm{NS}\end{array}$} \\
\hline & Male & 2 & 35 & 2 & \\
\hline & Female & 4 & 35 & 2 & \\
\hline \multirow[t]{5}{*}{3} & Religion & & & & \multirow{5}{*}{$\begin{array}{c}\chi_{2}^{2}=12.59 \\
\mathrm{df}=6 \\
\mathrm{NS}\end{array}$} \\
\hline & Hindu & 5 & 66 & 4 & \\
\hline & Muslim & - & 1 & - & \\
\hline & Christian & - & 1 & - & \\
\hline & Others & 1 & 2 & - & \\
\hline \multicolumn{3}{|c|}{ S: significant } & not significant & df : degree of & \\
\hline
\end{tabular}


Table 6: Association of level of attitude with age, sex and religion

\begin{tabular}{|c|c|c|c|}
\hline $\begin{array}{c}\text { Socio-demographic } \\
\text { variables }\end{array}$ & $\begin{array}{c}\text { Neutral } \\
\mathbf{n}\end{array}$ & $\begin{array}{c}\text { Favourable } \\
\mathbf{N}\end{array}$ & $X^{2}$ value \\
\hline \multicolumn{3}{|l|}{ Age in years } & \multirow{5}{*}{$\begin{array}{c}\chi^{2}=7.82 \\
\mathrm{df}=3 \\
\mathrm{NS}\end{array}$} \\
\hline $16-18$ years & 24 & 2 & \\
\hline 19-21 years & 47 & 6 & \\
\hline 22-24 years & 1 & - & \\
\hline $25-27$ years & - & - & \\
\hline \multicolumn{3}{|l|}{ Sex } & \multirow{3}{*}{$\begin{array}{c}\chi^{2}=3.84 \\
\mathrm{df}=1 \\
\mathrm{NS}\end{array}$} \\
\hline Male & 32 & 7 & \\
\hline Female & 39 & 2 & \\
\hline \multicolumn{3}{|l|}{ Religion } & \multirow{5}{*}{$\begin{array}{c}\chi^{2}=7.82 \\
\mathrm{df}=3 \\
\mathrm{NS}\end{array}$} \\
\hline Hindu & 67 & 8 & \\
\hline Muslim & 1 & - & \\
\hline Christian & 1 & - & \\
\hline Others & 3 & - & \\
\hline \multicolumn{2}{|c|}{ S: signif } & df: degree of $t$ & \\
\hline
\end{tabular}

\section{DISCUSSION}

In this study, the participants were of younger age group and $60 \%$ of participants had previous knowledge about umbilical cord blood and cord blood banking. Most of the participants received this knowledge from electronic media (33.33\%), followed by health professionals (25\%) and cord blood bank (news letter or pamphlets) (4.17\%). The study conducted among Greek citizens, showed that only $48 \%$ of respondents knew about umbilical cord blood. The main sources of information were media (35\%) and doctor (25\%). ${ }^{11}$

In this study, the overall knowledge of college students was $60.14 \%$ for umbilical cord blood and umbilical cord blood banking. The study conducted by Poomalar et al., 2016 in Pondicherry, India showed that 54\% of pregnant women had knowledge on applications of umbilical cord blood. ${ }^{12}$ Similarly, According to Perlow et al. 2006, showed that $37 \%$ had no knowledge of umbilical cord blood banking and study also indicated that educated and older patients were more aware of umbilical cord blood banking. ${ }^{13}$ In the same way, the study conducted among doctors and lay persons by Tanuja et al., 2016, reported that $58 \%$ of doctors and $82 \%$ of lay person did not have knowledge of use of cord blood in transplantation..$^{10}$ According to Ozturk et al., 2017, the study conducted in Turkey among mothers showed that $29.8 \%$ of mothers knew about cord blood and stem cells and their uses in medical treatment. ${ }^{14}$ Similarly, according to Venugopal et al, study conducted among nurses at All India Institute of Medical Sciences (AIIMS), New Delhi, India showed good knowledge i.e. 42.9\% regarding stem cells and UCBB. ${ }^{15}$ The study conducted by Pandey et al 2016 showed $26.5 \%$ of pregnant women had knowledge about umbilical cord blood. ${ }^{16}$ According to Jadwat et al 2018, the study conducted in Saudi Arabia showed a severe lack of knowledge about cord blood banking and more than half of the subjects were unaware of cord blood banking and its applications. ${ }^{17}$

In this study, the overall knowledge assessment shows that majority $87.5 \%$ of subjects had moderately adequate knowledge and $7.5 \%$ of subjects had inadequate knowledge and $5 \%$ of subjects exhibited adequate knowledge regarding cord blood banking. According to Parlow et al., 2016 2.6\% felt extremely knowledgeable while $74 \%$ felt minimally informed. ${ }^{11}$ Similarly, the study conducted by Peter et al in Kerala among nursing student showed $76 \%$ of student nurses had moderate knowledge and $23 \%$ had poor knowledge 
about umbilical cord stem cell banking. ${ }^{18}$

In this study, the overall attitude score of subjects was $51.25 \%$. Among the study subjects, 90\% had neutral attitude, $10 \%$ exhibited positive attitude and none of the subjects exhibited negative attitude towards cord blood banking. This finding is supported by study conducted at All India Institute of Medical Sciences (AIIMS), New Delhi, India by Venugopal that showed that $78.6 \%$ of nurses had neutral attitude. ${ }^{15}$ Similarly, study conducted in urban area of Pondicherry, India by Poomalar et al 2016 showed that $72 \%$ of pregnant women had positive attitude after knowing about umbilical cord blood importance and implications. ${ }^{12}$ The study conducted among Greek citizens also showed positive attitude towards umbilical cord blood and donated umbilical cord blood. ${ }^{11}$

Clinically, umbilical cord blood has been used for transplantation therapy in children and adults with a wide variety of malignant and nonmalignant diseases. The malignant diseases are acute lymphocytic leukemia, juvenile myelomonocytic leukemia, acute myeloid leukemia, lymphoma, chronic lymphocytic leukemia, myelodysplastic syndrome, chronic myelogenous leukemia, neuroblastoma and common variable immunodeficiency-myelodysplastic syndrome. The nonmalignant diseases are sickle cell disease, thalassemia, severe aplastic anemia, Lesch-Nyhan disease, severe combined immunodeficiency. ${ }^{19-21}$ As the college students (younger age group)are future parents and if they have adequate knowledge on umbilical cord blood and its importance, they can preserve or donate umbilical cord blood to cord blood bank for future use by their family members or others for the treatment of different diseases. In this study, only few of the students have adequate knowledge and most of them have neutral attitude on umbilical cord blood and cord blood banking. Therefore, we recommend that a topic on umbilical cord blood be introduced in syllabus or knowledge on this topic can be given with help of pamphlets, social media and health workers so that even larger number of students have positive attitude towards the umbilical cord blood and cord blood banking.

\section{CONCLUSION}

The findings from this study indicate that the majority of the respondents had moderate knowledge and maximum number of participants had neutral attitude on umbilical cord blood and umbilical cord blood banking. College students are future parents; therefore, knowledge of cord blood and cord blood banking may help them know the importance and utility of cord blood and cord blood banking in the future.

\section{Conflict of interest: None}

\section{REFERENCES}

1. Aznar J, Sánchez JL. Embryonic stem cells: are useful in clinic treatments? J Physiol Biochem. 2011 Mar;67(1):141-4. [PubMed | Full Text | DOI]

2. Park SK and Won JH. Usefulness of Umbilical Cord Blood Cells in Era of Hematopoiesis Research. Int J Stem Cells. 2009 Nov;2(2):90-6. [PubMed | Full Text | DOI]

3. Broxmeyer HE. Umbilical cord transplantation: epilogue. Semin hematology. 2010 Jan;47(1):97-103. [PubMed | Full Text | DOI]

4. Nietfeld JJ, Pasquini MC, Logan BR, Verter F, Horowitz MM. Lifetime probabilities of hematopoietic stem cell transplantation in the U.S. Biol Blood Marrow Transplant. 2008 Mar;14(3):316-22. [PubMed | Full Text | DOI]

5. Cohen Y, Nagler A. Umbilical cord blood transplantation - how, when and for whom? Blood Rev. 2004 Sep;18:167-79. [PubMed | Full Text | DOI]

6. Rocha V, Labopin M, Sanz G, Arcese W, Schwerdtfeger R, Bosi A, et al. Transplants of umbilical cord blood or bone marrow from unrelated donors in adults with acute leukemia. N Engl J Med. 2004 Nov;351:2276-85. [PubMed | Full Text | DOI] 
7. Shen BJ, Zhang HQ,Sui XW.Unrelated.HLA-mismatched multiple human umbilical cord blood transfusion in four cases with advanced solid tumours: initial studies. Blood cells. 1994 Jan;2O(2-3):285-92. [PubMed | Full Text | DOI]

8. De Lima M, St John LS, Wieder ED, Lee MS, Mc Mannis J, Karandish S, et al. Double-chimerism after transplantation of two human leucocyte antigen mismatched, unrelated cord blood units. Br J Haematol. 2002 Dec;119(3):773-6. [PubMed | Full Text | DOI]

9. Fraser JK, Cairo MS, Wagner EL, McCurdy PR, Baxter-Lowe LA, Carter SL, et al. Cord blood transplantation study (COBLT): cord blood bank standard operating procedures. J Hematother. 1998 Dec;7(6):521-61. [PubMed | Full Text | DOI]

10. Broxmeyer HE, Srour EF, Hangoc G, Cooper S, Anderson SA, Bodine DM. High-efficiency recovery of functional hematopoietic progenitor and stem cells from human cord blood cryopreserved for 15 years. Proc Natl Acad Sci USA. 2003 Jan; 100:645-50. [PubMed | Full Text | DOI]

11. Karagiorgou LZ, Pantazopoulou MN, Mainas NC, Beloukas AI, Kriebardis AG. Knowledge about umbilical cord blood banking among Greek citizens. Blood Transfus. 2014 Jan;12 Suppl s353-6o. [PubMed | Full Text | DOI]

12. Poomalar GK, Jayasree M. Awareness of cord blood banking among pregnant women in semi urban area. Int J Reprod Contracept Obstet Gynecol. 2016 Aug;5(8):2601-6. [PubMed | Full Text | DOI]

13. Perlow JH. Patients' knowledge of umbilical cord blood banking. J Reprod Med. 2006 Aug;51(8):642-8. [PubMed | Full Text | DOI]

14. Ozturk S, Tufekci FG, Kara A, Kilic M. Knowledge and Attitudes about cord blood and cord blood banking: Cross sectional study. International Journal of Caring Sciences. 2017Jan;10(1):335-41. [PubMed | Full Text | DOI]

15. Venugopal A., Joshi P., Deka D., Seth T. Knowledge and attitude of nurses regarding stem cells and umbilical cord blood banking in a selected tertiary care facility. Asian J. Nur. Edu. and Research. 2016 April;6(2):240-44. [PubMed | Full Text | DOI]

16. Pandey D, Kaur S, Kamath A. Banking umbilical cord Blood (UCB) stem cells: awareness, attitude and expectations of potential donors from one of the largestpotential repository (India). PLoS One. 2016 May;11(5):11. [PubMed | Full Text | DOI]

17. Jawdat D, AlTwijri S, AlSemari A, Saade M, Alaskar A. Public Awareness on Cord Blood Banking in Saudi Arabia. Stem Cell Internationsl; 2018 Apr;1-5. [PubMed | Full Text | DOI]

18. Peter A, Maria A, Bijo A, Thomas AR, Varghese AM, Thomas A et al. The knowledge among student nurses regarding Umbilical Cord Stem Cell Banking. Asian J Nur Edu and Research. 2017 Mar;7(4):505-8. [PubMed | Full Text | DOI]

19. Gluckman E, Rocha V, Boyer-Chammard A, Locatelli F, Arcese W, Pasquini R, et al. Outcome of cord-blood transplantation from related and unrelated donors. N Engl J Med. 1997 Aug;337:373-81. [PubMed | Full Text | DOI]

20. Thomson BG, Robertson KA, Gowan D, Heilman D, Broxmeyer HE, Emanuel D, et al. Analysis of engraftment, graft-versus-host disease, and immune recovery following unrelated donor blood transplantation. Blood. 2000 Oct;96:2703-11. [PubMed | Full Text | DOI]

21. Rocha V, Cornish J, Sievers EL, Filipovich A, Locatelli F, Peters C, et al. Comparison of outcomes of unrelated bone marrow and umbilical cord blood transplants in children with acute leukemia. Blood. 2001 May;97:2962-71. [PubMed | Full Text | DOI] 